\title{
THE EFFECT OF CELEBRITY ENDORSER ON REPURCHASE INTENTION OF COSMETIC PRODUCTS IN MILLENIAL GENERATION
}

\author{
Maharani Chiquita, Yuliati Lilik Noor, Afendi Farit M. \\ School of Business, Bogor Agricultural University, Bogor, Indonesia \\ *E-mail: maharanichiquita@gmail.com
}

\begin{abstract}
The Indonesian cosmetics market is increasing along with the influence of global trends where the function of cosmetics is shifting as a basic necessity for the millennial generation. Currently, many cosmetic product marketing use the role of celebrity endorser to increase the role of the brand and the desire to repurchase. Companies also need to allocate a lot of marketing funds, thus they need to be careful in selecting celebrity endorser. The population in this study was millennial women who use decorative makeup cosmetics in all over Indonesia. The total respondent in this study was 200 . The criteria for respondents who were the sample in this study were women, 18-36 years old, living and in residence in Indonesia and have purchased decorative cosmetic products for the past year. The problems that occur were analyzed using the structural equation modeling method. The results show that celebrity endorser has a significant positive effect on brand attitude, brand credibility, and self-brand connection. Celebrity endorser has an effect on repurchase intention through the brand attitude mediator variable (full mediation). Meanwhile, the variables of brand credibility and self-brand connection have a positive but insignificant effect on repurchase intention.
\end{abstract}

\section{KEY WORDS}

Celebrity endorser, brand attitude, brand credibility, millennial, repurchase intention, self brand connection.

The digital era has become a global issue that affects various technological, social, and economic developments. The digital era has triggered lifestyle changes and has become a challenge for generations to survive or be crushed by changes. Generational differences lead to new, undeniable changes. Howe and Strauss (2000) divided generations based on the point of year of birth: baby boomers, generation X, millennial generation and generation $\mathrm{Z}$. Millennial are the leading agents of disruption in the business competition map. The millennial behaviors are known to be unique, especially in shopping. Nearly $80 \%$ of millennial always read and look for product reviews before making a purchase decision (Mars Survey, 2016).

Building repurchase intention is not as easy as imagined, especially for the critical millennial, thus it challenges marketers to be more observant and creative in developing marketing communication strategies. Marketers are more intense to conduct brand campaigns in online and offline platforms, one of which is through advertising. The function of advertising - according to Shimp (2003) is to remind (reminding), in which to make a product brand be reminded in the minds of consumers. The advertising strategy that is often used in modern marketing today is celebrity endorser. Millennial have a tendency to follow the consumption patterns of celebrities they follow, both for products and brands that celebrities wear (McCormick 2016).

Cosmetics companies generally allocate a marketing budget of nearly $30 \%$ of production costs for celebrity endorser. The amount of this cost requires cosmetic companies to optimize the selection of celebrity endorser who are compatible/well suited with brand representations so that it leads to increased purchase intention. More so, there are several opinions that state that celebrity endorser have an effect on the effectiveness of brand credibility and purchase intention (Spray et al, 2011); besides, they also have a positive effect on brand attitude (Ranjbarian et al. 2010). However, there are still differences in the opinions that show a negative effect on purchase intention as stated in the researches that have been 
conducted by Hassan et.al. (2014) and by Kresnandi (2017) - that celebrity endorser do not have a significant effect on purchase intention, so it is necessary to further study the relationship between celebrity endorser, brand, and purchase intention. From these problems, this study aimed to examine the characteristics of millennial female consumers towards decorative cosmetic products and what factors affect the repurchase intention of cosmetic products in the millennial generation.

\section{LITERATURE REVIEW}

Millennials are the generation born between the year of $1982-2000$ or those who are 18-36 years old in 2020 (Howe and Strauss 2000). Leung (2003) explains that millennials are not grouped only based on demographics, but rather [based on] the similarity of values, life experiences, and purchasing behavior.

McCracken (1989) defines celebrity endorser as those who use public recognition to recommend or collaborate to support products in the form of advertisements. Shimp (2003) states that celebrity endorser are artists or celebrities [whose role] as advertising stars in mass media, from print media, social media, and television. Celebrities have demographic and psychographic connections with the target market to which is following those (Patra \& Datta, 2012).

Celebrity endorser based on their development in recent years is divided into two categories (Chahal, 2016):

1. Traditional celebrity, namely celebrities who are known to the public and already have the career [as celebrity] and are also known offline such as film players, musicians, athletes, entertainers, and so on;

2. Non-traditional celebrity, namely celebrities are known to the public for their careers in online platforms, digital celebrity groups such as influencers, bloggers, vloggers.

Attitudes according to Sumarwan (2015) are consumer responses or final evaluations related to the consumption process of objects, both products and brands. Attitudes are also seen as feelings or evaluations in general, both positive and negative, of the object (McGuire, 1986). The dimensions of one's own attitude according to Schiffman and Kanuk (2010) consist of cognitive in which is knowledge that shapes consumer perceptions obtained through experience and information from various sources; affective which describes the emotions and feelings of consumers, and; conative which is related to actions or behavior.

Kurniawati (2009) in her research states that consumer attitudes towards brands (brand attitude) can also be interpreted as conveying what consumers expect in order to satisfy their needs. Therefore, consumer attitudes can spur repurchase intention.

Brand credibility according to Erdem and Swait (2004) is the believability (ability to be trusted) of the product and information that is embedded in the brand. This brand credibility depends on the consumer's perception whether the brand has the ability and willingness to continue to deliver what has been promised. Brand is considered credible based on two dimensions. First, trustworthiness which refers to the willingness of companies to deliver what they have promised. Second, expertise which refers to a company's ability to deliver what they have promised. The more credible the brand is, the more likely it is that the brand will be included in the list of choices and will be chosen by consumers to be purchased/bought (Baek and King, 2011).

Self-brand connection according to Esclas and Battman (2004) is a concept and defined as consumers who integrate brands into their self-concept. The dimensions of the self-brand connection are:

1. Self-enhancement which means consumers are strongly influenced by the need to maintain and increase self-esteem;

2. Self-verification which means consumers have a need for self-knowledge, including self-verification;

3. Reconciliation self-enhancement and self-verification with two different self-needs goals, namely self-improvement and verification with two different self-needs goals, 
namely self-improvement and self-verification that are different from which they build and present self-concepts.

Purchase intention is something that arises after receiving stimulation from a product that one sees, and then there is an intention in purchasing / buying to have it (Kotler 2008). Repurchase intention refers to the possibility of using products and services again in the future; the general reason is [usually] the post-purchase experience (Chinamona \& Maziriri, 2017). Dimensions in measuring repurchase intention in this study are adopted from the purchase intention theory model developed by Ferdinand (2006), namely:

1. Transactional interest - the tendency of consumers to always repurchase the products they consume;

2. Referential interest - consumers' willingness to recommend a product they have consumed to others;

3. Preferential interest - consumers behavior that makes the products they have consumed the first choice;

4. Exploratory interest - the desire of consumers to always seek information about the products of interest.

\section{METHODS OF RESEARCH}

The population in this study was millennial women who use decorative makeup cosmetics in all over Indonesia. The criteria for the respondents were millennial women, 1836 years old (Howe and Strauss 2000), who have purchased decorative cosmetic products in the past year, live and/or in residence all over Indonesia, and are online transactions user. The total sample used in this study was 200 people (respondents) who were selected / chosen using the purposive sampling technique. Data were collected in January and February 2019. This study used a quantitative approach with the survey method.

The data used were primary data obtained through the questionnaires while additional data from previous studies in books and scientific writings on the internet were used as supports in completing the information. The instrument used to conduct data collection from the respondents was a structured questionnaire. The data collection was conducted by distributing questionnaires online through the google form to the target respondents extensively.

The data analysis method used in this study was the Structural Equation Model (SEM); this method was used to test the relationships between variables in a model, both between indicators and constructs, or relationships between constructs. Data were analyzed using descriptive analysis to find out and get a picture of the study being carried out with the support of relevant data.

\section{RESULTS AND DISCUSSION}

The majority of consumer respondents in this study are millennial women who are 2832 years old (44\%) and work as private employees $(51.5 \%)$. These millennial respondents have monthly expenses of Rp. 2,800,000 - Rp. 4,250,000 (30\%). The expenditure of these millennial respondents on decorative cosmetics is $<\mathrm{Rp}$. 1,000,000 per year. The most frequently purchased products by these millennial respondents are lipsticks (75\%) under Wardah and Maybelline brands. The most often used media to find information about decorative cosmetics by these millennial respondents is Instagram (72\%).

Hypothesis testing was done using the Structural Equation Modeling (SEM) method. The estimation results of the SEM model can be seen in Table 1. All variables have a positive effect on other variables but not all have a significant effect. The significant effect between variables is the celebrity endorser on the brand attitude, brand credibility, and self-brand connection, as well as, the brand attitude on the repurchase intention. Meanwhile, the celebrity endorser, brand credibility, and self-brand connection variables have no significant effect on the repurchase intention variable. 
Table 1 - SEM Model Estimation Results

\begin{tabular}{|c|c|c|c|c|c|c|}
\hline \multicolumn{2}{|c|}{ Variable } & Estimate & S.E. & T statistics & $P$ value & Label \\
\hline 1 & CE --> BA & 0.894 & 0.055 & 16.358 & 0.000 & Signifikan \\
\hline 2 & CE --> BC & 0.562 & 0.055 & 10.232 & 0.000 & Signifikan \\
\hline 3 & CE --> SBC & 0.966 & 0.059 & 16.473 & $0.000^{\text {xax }}$ & Signifikan \\
\hline 4 & CE --> RPI & 0.262 & 0.195 & 1.343 & 0.179 & Tidak Signifikan \\
\hline 5 & BA --> RPI & 0.375 & 0.126 & 2.971 & $0.003^{x \times}$ & Signifikan \\
\hline 6 & BC --> RPI & 0.040 & 0.041 & 0.979 & 0.328 & Tidak Signifikan \\
\hline 7 & SBC --> RPI & 0.222 & 0.133 & 1.661 & 0.097 & Signifikan \\
\hline
\end{tabular}

Note: ${ }^{* * *}$ sig level of $0.01,{ }^{* *}$ sig level of 0.05 .

Celebrity endorser positively and significantly related to brand attitude as seen from the estimated value of 0.894 , t-statistics of 16.358 and a $p$ value of 0.000 which is less than 0.05 . If the celebrity endorser quality is increased $100 \%$, it is assumed that it will increase the brand attitude by $89.4 \%$ positively and significantly. The researches results of Aji (2018) and Saragih et al. (2018) show that celebrity endorser have a significant positive effect on brand attitude. The positive attitude of consumers is formed from the evaluation of consumers' feelings of liking for decorative cosmetic brands, besides that this significant effect is also caused by the celebrity endorser ability to attract millennial consumers' attention, which means that the celebrity endorser deserve to be used as brand representatives, have characters that can affect/influence consumers, thereby increasing the attitude towards the brand.

The celebrity endorser variable has a positive and significant effect on brand credibility. This can be seen from the t statistic of 10.232, which is greater than 1.96; and the $p$ value of 0.0000 (less than 0.05 ). This indicates that celebrity endorser who has achievements can be trusted and are considered experts in their fields in conveying messages and information according to millennial consumers; thereby they are able to increase the credibility of cosmetic brands. These results are supported by the research results by Spry et al. (2011) in which state that celebrity credibility has an impact on consumers' opinion that the brand being marketed also has credibility.

The celebrity endorser variable has a positive relationship direction to self-brand connection. This can be seen from the estimate value of 0.966 . The celebrity endorser variable has a significant effect on self-brand connection as seen from the t statistical value of 16.473 which is greater than 1.96 and the $p$ value of 0.000 which is less than 0.05 (Table 1). This indicates that the role of celebrity endorser as representatives of a cosmetic brand turns out to be able to form integration with millennial consumers. This is believed because the use of the right celebrity as an endorser can [indeed] give impulses to consumers of cosmetic brands so that millennial consumers are able to have an emotional relationship with the brand, consider the brand as a reflection of themselves, and the use of cosmetic brands as a form of communication can increase self-brand connection to consumers. Dwivedi, Johnson, and McDonald (2015) also state that the credibility of a celebrity endorser has a significant positive effect on self-brand connection.

Celebrity endorser has a positive relationship to repurchase intention. The direction of the relationship can be seen from the estimate value of 0.262 . However, the celebrity endorser variable does not have a significant effect on the repurchase intention variable because the obtained t statistics of 1.343 which is less than 1.96 and $p$ value of 0.179 which is greater than 0.05 . An insignificant effect could occur due to mediation by other variables, namely brand attitude, brand credibility, and self-brand connection. This mediation makes the indirect effect of celebrity endorser on repurchase intention large. The positive effect that is brought by the use of celebrity endorser cannot be eliminated, in which the role of celebrity endorser here is as a media link between the brands and millennial consumers in the initial purchase, but celebrity endorser cannot directly affect/influence repurchase intention because there is personal experience of the consumers when using the cosmetics and the level of compatibility with skin sensitivity.

The variable that has an indirect effect on repurchase intention is the celebrity endorser variable. The celebrity endorser variable has an indirect effect on repurchase intention of 
0.572. The total effect between the celebrity endorser variable and repurchase intention is 0.833. Brand attitude is an intervening variable between the celebrity endorser and repurchase intention variables. Because the celebrity endorser variable cannot directly influence/affect repurchase intention, the effect is full mediation wherein the celebrity endorser variable can influence the repurchase intention variable through the brand attitude variable.

Brand attitude has a positive relationship to repurchase intention. The direction of the relationship can be seen from the estimate value of 0.375 . Brand attitude has a significant effect on repurchase intention based on a statistical t value of 2.971which greater than 1.96 and a $p$ value of 0.003 which is less than 0.05 . This positive and significant influence is reflected in the attitude towards the brands; millennial consumers who like the variety of color, composition/formula that is suitable for their skin will have an increase in intention to repurchase [the product] in the future, especially if the quality brand offered matches the price obtained. These results are in accordance with the statement of Hanfan (2017) and Aji (2018) who reveal brand attitude has a significant positive effect on repurchase intention.

Brand credibility has a positive but not significant effect on repurchase intention. This is because obtained t statistical value of 0.979 which is less than 1.96 and $p$ value of 0.328 which is greater than 0.05 . Brand credibility has a positive relationship to repurchase intention as seen from the estimated value of 0.040 . This positive results still indicate that the high credibility of a cosmetic brand, such as being able to maintain the promise, can increase consumer repurchase intention; but millennial consumers are known for their character to easily switch products - thus, if the cosmetic brand does not innovate with the appropriate color, composition/formula, it will cause boredom for millennial consumers that makes them not to repeat purchases. These results are in contrast with the researches results by Leischnig et al. (2012) and Faisal (2015) which state that there is a positive and significant relationship between brand credibility and repurchase intention.

The obtained $t$ statistics for this variable is 1.661 which is less than 1.96 and a $p$ value of 0.097 which is greater than 0.05 , meaning that the self-brand connection variable has positive but not significant effect on repurchase intention. The positive results in this study indicate that the increasing need for consumers to adapt the brand image to their identity can increase the repurchase intention in a product. The positive effect of self-brand on repurchase intention is because millennial consumers are known to have a self-concept that follows the trend. The brand of a decorative cosmetic product is able to help millennial consumers as a form of self-communication but this does not significantly increase millennial consumer repurchase intention because it all returns to the basic principle of using cosmetic products which are known to be quite sensitive to the skin, thus millennial consumers will only repurchase at decorative cosmetic products that are preferred and suitable for them (suitable for their skin condition). These results are in accordance with the results of research by Kircova et al. (2015) which reveal that self-brand connection has no significant effect on repurchase intention.

\section{DISCUSSION OF RESULTS}

This study aimed to analyze the characteristics of millennial consumers who use decorative cosmetics, to identify and analyze the factors that affect the repurchase intention of cosmetic products in the millennial generation. From this study, it can be seen that the use of social media (especially Instagram) is very dominant (72\%) among millennials to access information sources, messages from celebrity endorser and from a brand promotions which ultimately determine their intention and purchase decisions as well as repurchase intention of their cosmetic products. A total of $54 \%$ respondents buy/purchase cosmetic products at official outlets, meanwhile $20 \%$ of them purchase [cosmetic products] through e-commerce. The role of Celebrity Endorser in repurchases is seen with the mediation of Brand Attitude.

Based on the research results, it can be seen that the variable that has a direct effect on repurchase intention is the brand attitude variable, while the other variables have no direct relationship with repurchase intention. In this model there is also full mediation between 
celebrity endorser and repurchase intention through brand attitude. These findings have the following managerial implications:

1. To conduct advertising campaigns on Instagram social media. Instagram is chosen by $72 \%$ of the millennial consumers as a media to find information about decorative cosmetic products. This can build/establish attitudes towards consumer brands and then increase the repurchase intention of the content built on the Instagram page.

2. To strengthen the Research \& Development division as well as marketing division to make innovations related to color variations of decorative cosmetic products, product formulas and composition to be then match the price and quality that can make millennial consumers consider repeating purchases.

\section{CONCLUSION}

The majority of consumer respondents in this study are millennial women who are 2832 years old and work as private employees. These millennial respondents have monthly expenses of Rp. 2,800,000 - Rp. 4,250,000. However, their expenditure on decorative cosmetics is < IDR $1,000,000$. The most frequently purchased products are lipsticks and the most purchased brands in each decorative cosmetic product are Wardah and Maybelline. The main source of information for millennials is Instagram.

The celebrity endorser relationship has a significant positive effect on brand attitude, brand credibility, and self-brand connection. The variable that has a significant effect on repurchase intention is brand attitude, while the other three variables such as celebrity endorser, brand credibility, and self-brand connection have a positive and insignificant effect on repurchase intention. The celebrity endorser variable has an effect on the repurchase intention variable through the brand attitude variable (full mediation). The celebrity endorser variable has an indirect effect on the repurchase intention variable. This is possible because millennial consumers have different experiences in using cosmetics. When they first want to buy decorative cosmetics, they will be interested in the products offered by celebrity endorser but the experience they got after trying these products make consumers either to repurchase or not repurchase the product. Consumers do not repurchase the product may be because these products do not match their expectation, both in terms of skin suitability and function and price comparisons. Based on the results of this study, it is known that celebrity endorser can help companies to increase their sales, thus companies must be careful in choosing/selecting celebrity endorser, especially the celebrity endorser for cosmetic brands representation.

This study has some limitations, namely references to previous studies regarding the theory and application of self-brand connection and repurchase intention are limited, especially in the cosmetics industry. In addition, there is no identity of the respondent on the data collection instrument, thus the researchers could not carry out tracing and elaboration of the respondents' answers to enrich the research results. The researchers also could not limit the number of questionnaires that are distributed online through Google Forms, so the researchers could not supervise the questionnaire filling process. This causes the possibility of respondents filling out the questionnaire in a dishonest and hasty manner so that the results tend to be biased.

\section{REFERENCES}

1. Aji LPM. 2018. The influence of celebrity endorser and attitudes on advertising towrads attitudes on brand and repurchase intention. International Journal of Social Science and Business. 2(2):46-54.doi: 10.23887/ijssb.v2i2.16205.

2. Augusty Ferdinand. 2006. Metode Penelitian Manajemen :Pedoman Penelitian Untuk Penulisan Skripsi, Tesis, dan Disertasi Ilmu Manajemen. Semarang: Badan Penerbit Universitas Diponegoro.

3. Baek,T.H., King, K.W.(2011). Exploring the consequences of brand credibility in services. Journal of Services of Sales Marketing, 25(4), 260-272. 
4. Chahal, M. (2016). Four trends that will shape media in 2016. [online] Marketing Week (2016_ from: http://www.marketingweek.com/2016/01/08/four-trends-that-will-shapemedia-in-2016.

5. Chinomona R, Maziriri ET. 2017. The influence of brand awareness, brand association and product quality on brand loyalty and repurchase intention: a case of male consumers for cosmetic brands in South Africa. Journal of Business and Retail Management Research, 12(1):143.

6. Dwivedi A, Johnson LW, McDonald RE. 2015. Celebrity endorsement, self-brand connection and consumer-based brand equity. Journal of Product \& Brand Management.24(5):449-461.doi:10.1108/JPBM-10-2014-0722.

7. Erdem T, Swait J.1998. Brand equity as a signalling phenomenon. Journal of Consumer Psychology. 7(2):131-157.doi:10.1207/s15327663jcp0702_02.

8. Escalas JE.2004. Narrative processing: Building consumer connections to brands. $\begin{array}{llll}\text { Journal of } & \text { Consumer } & \text { 168-180. }\end{array}$ doi:10.1207/s15327663jcp1401\&2_19.

9. Faisal A. 2015. Pengaruh brand credibility terhadap information efficiency dan risk reduction, serta dampaknya atas repurchase intention. Jurnal Manajemen dan Pemasaran Jasa. 8(1): 1-14. doi:10.25105/jmpj.v8i1.1397.

10. Hanfan A. 2017. Mengeksplorasi kesadaran merek terhadap minat beli ulang melalui sikap terhadap merek. Performance. 24(2): 42-49. doi: 0.20884/1.performance. 2017.24.2.699.

11. Howe Howe, N. \& Strauss, W. (2000). Millennials rising: The next great generation. New York: Vintage.

12. Kırcovaa İ, Enginkayaa E, Yılmaza H. 2015. Influence of consumers' self-brand connections on purchase intentions. Di dalam: Donduran M, Uzunöz M, BulutE, Çadirci TO, Aksoy T, editor. Annual International Conference on Social Sciences; 2015 May 2123; Istanbul, Turkey. Istanbul (TR): AICSS. hlm 491-504.

13. Kotler, Philip. 2008. Manajemen Pemasaran Edisi 12 Jilid 2. Jakarta: Indeks.

14. Leischnig A, Geigenmüller A, Enke M. 2012. Brands you can rely on! An empirical investigation of brand credibility in services. Schmalenbach Business Review. 64: 44-58. doi:10.1007/BF03396837.

15. Leung, C. M. (2003). Neuropsychopharmacology: The fifth generation of progress. Hong Kong Journal of Psychiatry, 13(3), 31.

16. McCracken, G. (1989). "Who is the celebrity endorser? Cultural foundation of the endorsement process." Journal of Consumer Research. 16 (3), 310-321.

17. McGuire,W J,1986. Public Communication and Behaviour,Orlando. FL: Academic Press.

18. Patra, Supriyo dan Saroj Kumar Datta. 2010. Indian Sports Celebrities as Brand Endorsers: An Analysis Based on 'Q' Score Technique, The IUP Journal of Marketing Management, Vol.9 No.3, pp.57-70.

19. Schiffman, L.G., \& Kanuk, L.L. (2010). Consumer Behaviour (10th ed). New Jersey, Pearson Prentice Hall.

20. Sumarwan, Ujang. 2015. Perilaku Konsumen Teori Penerapannya Dalam Pemasaran Edisi Kedua. Cetakan Ketiga. Bogor: Penerbit Ghalia Indonesia. 